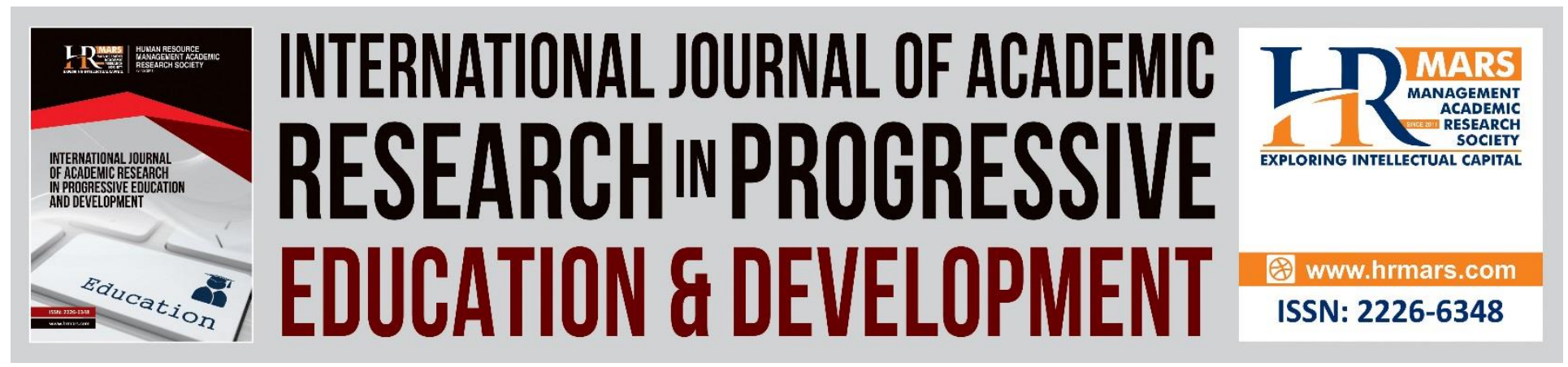

\title{
The Effects of Computerized Learning Games on the Third Grade Students in Karak Governorate
}

Nesreen Abdullah Khalifeh Khatatneh, Kamarul Shukri Mat Teh

To Link this Article: http://dx.doi.org/10.6007/IJARPED/v7-i2/4464

DOI: $10.6007 /$ IJARPED/v7-i2/4464

Received: 29 March 2018, Revised: 21 April 2018, Accepted: 16 May 2018

Published Online: 03 June 2018

In-Text Citation: (Khatatneh \& Teh, 2018)

To Cite this Article: Khatatneh, N. A. K., \& Teh, K. S. M. (2018). The Effects of Computerized Learning Games on the Third Grade Students in Karak Governorate. International Journal of Academic Research in Progressive Education and Development, 7(2), 96-111.

Copyright: (C) 2018 The Author(s)

Published by Human Resource Management Academic Research Society (www.hrmars.com)

This article is published under the Creative Commons Attribution (CC BY 4.0) license. Anyone may reproduce, distribute, translate and create derivative works of this article (for both commercial and non-commercial purposes), subject to full attribution to the original publication and authors. The full terms of this license may be seen at: http://creativecommons.org/licences/by/4.0/legalcode

Vol. 7, No. 2, April 2018, Pg. 96 - 111

Full Terms \& Conditions of access and use can be found at http://hrmars.com/index.php/pages/detail/publication-ethics 


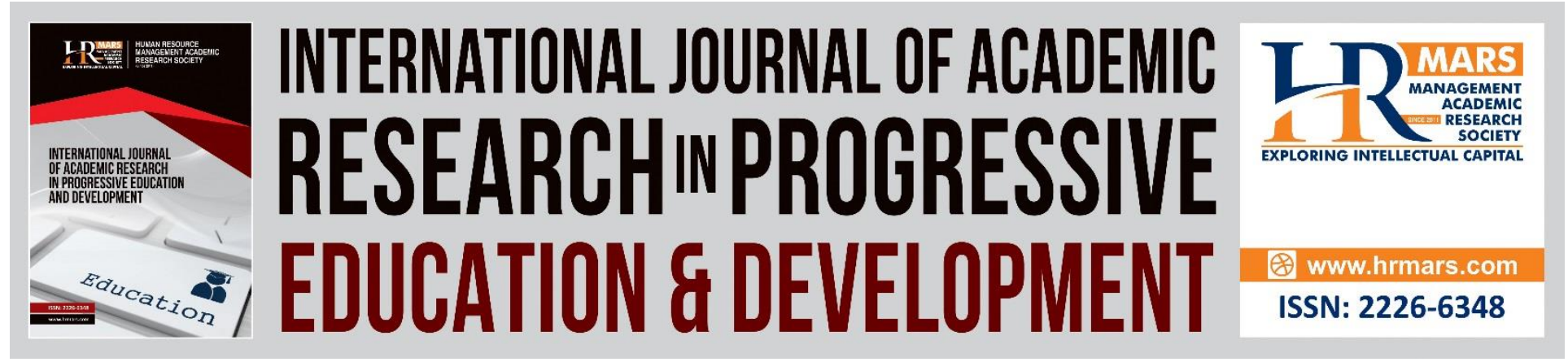

\title{
The Effects of Computerized Learning Games on the Third Grade Students in Karak Governorate
}

\author{
Nesreen Abdullah Khalifeh Khatatneh \\ Kamarul Shukri Mat Teh \\ Faculty of Islamic Contemporary Studies, Universiti Sultan Zainal Abidin, Gong Badak Campus, \\ 21300 Kuala Terengganu, Malaysia \\ Email: nessren201421@gmail.com, kamarul@unisza.edu.my
}

\begin{abstract}
This study is aimed at identifying the effects of computerized learning games on the third-grade students within Karak Governorate and further evaluates the achievements recorded in the application of English language at various schools. A total number of 60 third grade students were selected as the targeted sample and are divided into two (2) groups namely; a control group of 30 male and female students were evaluated comprehensively using a traditional approach, while the other group of 30 students comprising of both genders were equally examined using a computerized learning games. To ensure efficiency, pre and post achievement tests was applied to measure and record the achievement of these two (2) groups. The results showed that the achievement level in English language as recorded by the third-grade students was medium. Further result indicated the existence of a significant impact of computerized learning games in enhancing the achievement of third grade student in English language at various schools in Karak governorate. Moreover, no meaningful effect or significant differences was reported on the effects of using computerized learning games on the students' achievement by gender. In light of the results of this study therefore, there is need to recognize the significant effects of computerized learning games in the design of educational policies. The essential relevance of these computer learning games cannot be undermined particularly in the contemporary era, hence the growing need by the government to advocates publicity campaign towards national growth and development.
\end{abstract}

Keywords: Computerized learning games, third grade students, Karak Governorate, English language.

\section{Introduction}

Across the globe, governments of numerous countries have considered that learning English language as a means of communication is a strategic goal towards national growth and development. This has not come as a surprise, since the language emerged as the world most 
Vol. 7, No. 2, April 2018, E-ISSN: 2226-6348 @ 2018 HRMARS

widely spoken international language. As supported by Al-Ahmadi (2011), the significance of learning cannot be overemphasized given the present generation. It is clear from the literature that higher education institutions in all countries across the world especially the third world economies, encourage students to pursue and seek for further knowledge of English language to enable them compete globally and keep pace with progress and modern technology as much as they could learned it during especially during childhood stage together with the mother tongue (Al-Ahmadi, 2011).

Interestingly, teaching language by applying games is one of the most influential methods of behavior and learning; it is an effective way to improve students' language skills and it plays a crucial role in teaching children. This method of learning has demonstrated full potentials in encouraging children to politely talk to adults and their peers as a way to practice it.

Accordingly, children are also encouraged by respective teachers to speak and communicate in English, hence to improve the learning process. This method is useful in learning how to listen to children, how to comment on topics, how to consult and interact with younger, and also ask the children about their tasks and why they did not finish the tasks. Evidence by Abdel Baqi (2001) indicated that the method is designed to encourage children towards expressing their feelings in a verbal way. Further submission by Obied (2007) indicated that playing during child's life is a fun, a productive activity, an effective preparation for future life, a natural and genuine use of language during which the child favors his voice, tunes his words, constructs his sentence, and expresses his thoughts.

In addition, learning games are also important hence; it is an effective means of imparting alphabets and vocabulary for students as it would stimulate their motivation and interfere with learning. Likewise, Qandil and Badawi (2007) reported that children like playing; and this enriches and develops their linguistic growth, and teachers use games in the classroom to help learners acquire language interestingly and enjoyably. Undeniably, games assist in teaching many aspects of language including the vocabulary, grammar, and language patterns. More so, it helps in teaching the children some required values and social skills towards better upbringing.

Given its significance, the computer or electronic learning games are perceived as an important programs and a vital strategy to draw students' attention towards teaching them different concepts. This strategy can be applied to all subjects, at all ages and at cognitive levels of learners (Al-Ghazu, 2004). Learning computerized programs are based on integrating the learning process by playing in a recreational model where students compete for gaining points. To end this, it requires to solve the problem of computational or logical dilemma. Learners can therefore read and explain some guidelines and answer some questions about certain topics. When doing so, learning games add excitement and motivation to the school work and other curricular activities. Also, computerized learning games usually attracts the learner and makes him not to quit the game without achieving the required goals or objectives in one way or other, and this is definitely based on the principle of competition to stir the learner's motivation. Additionally, it depends on the potential of learning computer when it becomes possible to evaluate the learner's performance through some exercises that are dealt with indirectly, which increases the likelihood of achieving the objectives of the lesson (Melhem, 2002).

Furthermore, computerized learning games contribute to the learner's understanding of concepts, information and knowledge about the surrounding environment. When playing, the learners can recognize the characteristics of sensory objects and their similarities and differences, 
Vol. 7, No. 2, April 2018, E-ISSN: 2226-6348 @ 2018 HRMARS

as well as assist in the self-knowledge. The learner may know, through experience and exploration, what they likes, what they tends to, and what meets their potential needs in line with how to identify and solve any critical problem (Al-Anani, 2002). Notwithstanding, there are particular elements and certain criteria that must be met in the electronic learning games; and these elements includes (a) adaptation: where the different learning patterns, different previous information, and different goals of learners must be attained, (b) excited and positive response: that the learning environment and situational process in the electronic game must be presented to the learner since it is exciting and requires a positive response in this term to move to a new step, and (c) feedback and immediate reinforcement: as the learner has responded to the excitement, the learning game presents the immediate result and serves as reinforcement for the learners that drives them to continue playing (Moreno-Ger et al., 2008). More to that, learning games are a modern means and methods used in teaching various subjects such as language, mathematics, science, and sociology (Leonard \& Tracy, 1993). When this method is properly applied, numerous benefits would be attained especially as the society lives in the twenty-first century, and in light of the explosion of various technological revolution in all areas of life. Therefore, there is need to prepare the society most especially the children to coexist with current trend of the $21^{\text {st }}$ century (Oldfield, 1991). This can be attained by increasing their knowledge and experience in various learning materials relating to its importance and multiple uses in different aspects of life (Najm, 2001: 103).

As observed among various students, there is a considerable weakness on the student's side at the first primary grades in English language achievement. This weakness may occur due to several reasons; few amongst include, the student himself is weak in English language, the school curriculum and the teaching methods. These weaknesses are consistent with the study by Nofal (2011). Further evidence as submitted by Abadi and Jaradat (2015) showed that there is weakness among certain students in terms of speaking English in their daily conversations and communications. Few students got high marks; yet they are less capable of reading or communicating in sound English. Others lack proficiency in some language skills such as reading, listening, writing, or speaking. Perhaps, the traditional methods followed by some teachers are a phenomenon that needs to be evaluated. Indoctrination, for instance, is still used by certain teachers, and by this method; the student is not involved in the educational process even though at better cases, some discussions are dominated by distance from teaching and interactive teaching methods. Should these methods be used perfectly, it makes student feel more interactive, positive and participated (Tahaineh \& Daana, 2013).

Since the majority of students learn English theoretically rather than practically, they learned in a traditional method; and this method reduces the learner's interest depending on suspense and deactivates their role in the educational process. By this approach, many students may hardly learn English. As modern educational trends are keen to eliminate the traditional methods of teaching, and to activate the role of the learner to become the basis of the educational process, it is essential to use modern educational techniques that take technological development with high consideration.

Notably, the school environment is another essential factor that encouraged the students' poor achievement in English language, as well as the system curriculum which does not comprise the learner's needs to learn English, as indicated by the study of (Alshourafa, 2012). While Mumtaz (2001) indicted to the most important computer games and activities done by children increase 
Vol. 7, No. 2, April 2018, E-ISSN: 2226-6348 @ 2018 HRMARS

the fun that students feel during learning. Following the previous discussions therefore, this study is aimed at examining the effects of using computerized learning games on the student's achievement in English language.

In lieu of the various issues identified hitherto and other challenges associated with computerized learning games, this study raised a number of questions which are expected to serve as a guide to the study and further provides significance contribution to the literature. These interesting questions are: What is the level of student's achievement at the third grade in English language in Karak governorate? Is there any significant difference in learning computerized games on the achievement of third grade students by gender?

Given these issues, the study aimed to examine the level of student's achievement at the third grade in English language at Karak governorate by conducting a pre-test among students and investigating the use of computerized learning games at their respective schools within the experimental group. In addition, further aim is to detect the semantic differences at their achievement level within the experimental group that applied computer learning games due to gender.

\section{Study Hypotheses}

In this study, hypotheses were formulated and tested in accordance with the previous research questions. These hypotheses are stated as follows:

$\mathrm{H}_{1}$ : There is no significant effect at $(\alpha \leq 0.05)$ for applying computerized learning games on the third grade students' achievement in English language at Karak governorate within the experimental group.

$\mathrm{H}_{2}$ : There is no significant differences at $(\alpha \leq 0.05)$ between the mean scores of the experimental group who were taught by using computer learning games due to gender.

\section{Study Significance}

The significance of this study stems from the important role played by computerized learning games in learning and teaching processes. By this method, the study chooses an effective way to address the weakness of students in learning English language. In turn, the study provides English teachers with an educational tool to help them achieve their teaching goals and relieve them from the burden of traditional learning. It also opens wide doors towards computing techniques to be applied by teachers at all schools in Jordan. This study also provides a clear vision to high administrative officials and decision makers in the Ministry of Education to adopt decisions that can correct the weakness of student in English language due to the application of traditional methods. The study also reveals the impact of computer learning games on the achievement of third-grade students at the Karak governorate and compared same with the traditional methods. Basically, the age group is important in learning English and the targeted students are nine years old. This age bracket is regarded as tomorrow's leaders and is capable of making a meaningful impact on the nation's development.

\section{A Review of Conceptual and Empirical Literature}

Various concepts and terminologies are used in this study to explain the effects of computerized learning games on the student's achievement in English language. Although, there is no precise definition of these concepts as various scholars define them using certain terminologies. In other 
INTERNATIONAL JOURNAL OF ACADEMIC RESEARCH IN PROGRESSIVE EDUCATION AND DEVELOPMENT

Vol. 7, No. 2, April 2018, E-ISSN: 2226-6348 @ 2018 HRMARS

words, there is no consensus in the literature on the exact definition of computerized learning games. A number of definition as postulated by different authors are given as follows: Games: are physical inseparable needs from the child whether they relate to daily life or physiological needs in which play is a necessary basis for child growth and development, and the child therefore learns spontaneously and inherits from peers their local environment (Al-Helah, 2002). Meanwhile, Computerized Learning Games: stand for meaningful, directed, structured, and planned language activity in which students make great efforts to achieve the goals of learning skills in various subjects and areas within specific rules and regulations as supervised and monitored by teachers. In addition, these games assist the teacher and the learner to have an enjoyable way to train in learning skills and enhance progression, provide motives for developing different language skills, and apply some mental processes (Al-Helah \& Ghnem, 2002). Other concepts include the School Achievement: it stands for information, study data, skills and competencies which can be acquired through the learning process; scientific gains obtained through experience and expertise within the framework of educational curriculum in use (Mansi, 1991). Practically, it is the total number of grades obtained by the student after passing the examination.

Several empirical studies contributed to the literature on computer studies and its applications in educational process, particularly in the areas of teaching English language. Some of this literature includes the followings: Ibrahim (2011) conducted a study aimed at revealing the effectiveness of electronic learning games on the achievement of students at the fifth grade at primary schools in Khartoum. The researcher applied the experimental method. The sample consisted of 50 students from the fifth grade. While the study instruments were chosen by the researcher as an educational program for the games, as well as a pre-test and a post-student test. The results showed that there were statistically significant differences between the mean of the total number of students of the control and experimental groups in the post-test at the level of remembering and testing as a whole for the experimental group. There were no statistically significant differences between the mean of the total number of students of the control groups and the experimental in the post-test at the level of understanding.

In the work of Al-Ahmadi (2011), the study aimed at exploring the effect of applying learning games on the achievement of the sixth grade students in the alphabet and vocabulary of the English language. The study sample consisted of sixth grade students in one of the selected primary schools in Jeddah. The students were divided into two groups: the experimental group of 25 students, and the control group of 25 students. Findings revealed that there were statistically significant differences between the mean of the experimental and control groups in the post-test in learning the alphabets of the English language for experimental students.

Similarly, Al-Rimawi (2014) investigated the impact of integrated learning into the direct and deferred achievement of the sixth grade students in the English language. To achieve the objectives of the study, the experimental method was applied over 60 students from the Umm Qasir Primary School for Boys in the Directorate of Amman, Qweismeh Province. Then, the two sections were randomly assigned to control and experimental groups, and the results showed that there were statistically significant differences between the direct achievement means for the experimental group.

In addition, Shokri and Abdolmanafi-Rokn (2014) aimed to apply video games as one of the basic steps of learning the language and literacy skills among certain students in dictation. A total 
Vol. 7, No. 2, April 2018, E-ISSN: 2226-6348 @ 2018 HRMARS

number of 40 students were equally divided into experimental and control groups, where the first group had traditional learning. The latter was taught by using original computer games. The results showed that the experimental group surpassed the control group, and this result supports the role and effectiveness of computer video games on the performance of students in dictation. Furthermore, Al-Mashaqbeh (2015) conducted a study to identify the extent of the impact of a computerized learning program on the achievement of students of the first stage of graduation in Arabic grammar in Iraq. The sample was selected from the schools of Al-Wadiqar governorate in Iraq. One hundred and twenty male and female students were selected; 60 for the experimental group and 60 for control group. Then, the researcher applied the computer tutorial during teaching the experimental group tool, while the control group were taught by the traditional way. The study concluded to that there were no statistically significant differences between the mean group scores in the Arabic language between the experimental group and the control group, but no statistically significant differences between the means scores of the experimental group and the mean scores of the control group students due to the gender variable have been revealed.

Moreover, another study was conducted by Mehrpour (2017) on 60 Iranian students during their visit to children section at Iranian Language Institute to recognize the effect of computerized learning games on teaching English spelling. So, the students attended two full terms. One term was randomly assigned to the experimental group, where students were introduced to a computer learning game called Fun of Spelling. The control group was taught by traditional ways. After having the results of the data analyzed, they showed that the learning use of the game had a significant impact on the language learners among the experimental group in learning English language spelling in general and learning English and English words with silent messages, in particular.

\section{Data Collection and Methodology}

This study is based on the semi-experimental approach and utilizes non-random samples for the experimental vocabulary before dividing into groups. It is also required to distribute the sample items in a completely non-random way between the two groups. This approach is considered more appropriate and suitable for this kind of study.

Upon reviewing the previous studies and other theoretical literature on the impact of applying computerized learning games in teaching English language, the learning games were selected. The study selected the learning material which was taught by using computerized learning games from unit seven entitled "What are you doing? 60" and unit eight entitled "Review" of the third grade book in Jordan (Action Pack 3). A good number of computerized learning games were selected on the Internet and learning toys were also designed by PowerPoint using the Visual Basic for Applications (VBA) code. After identifying the learning games, they are selected to suit the students' age and their learning capabilities, their academic level, and the appropriate content.

There is the availability of technical standards for good learning games. The learning games were presented to seven (7) experts in the field of teaching English language and teaching techniques, where they expressed their opinions and observations on the relevance of English to third-grade students. 
Vol. 7, No. 2, April 2018, E-ISSN: 2226-6348 @ 2018 HRMARS

To answer the research questions and estimates the results, a Statistical Package for Social Sciences (SPSS) was applied to enhance and expedite the statistical analysis and estimation procedures. This is possible by using descriptive statistical measures in order to reveal the level of third grade students' achievement in English language based on frequency, percentages, means and standard deviations. In addition, ANCOVA was further applied to detect the impact of computerized software on student achievement.

\section{Study Population and Sample Size}

The population of this study consisted of 2336 male and female students of the third grade within various schools at Karak governorate. The rationale for chosen third-grade students as the targeted respondent is that this stage is considered as a basic stage in which students' development and learning can be clearly observed and monitored.

Out of the sample population, sixty (60) students of the third grade in the Directorate of Education of Karak Governorate were selected as the sample size and targeted respondents. These samples were divided into 30 students as control group who were taught by traditional way, and the other 30 students who were taught by applying computerized learning games. The targeted respondents were selected purposely who study at Al Qasabah directorate of education because it represents the largest number of population and it is characterized by a large number of schools; all situated nearby communities of other directorates and share similar status in terms of customs, culture and conditions of schools. Hence the results of this sample can be generalized across other school in the governorate.

\section{Study Instrument}

A test of 35 items was prepared to measure the level of third grade students' achievement in English language at the Karak governorate. It consists of several objective questions, such as multiple choice, filling the gaps and match the word to the picture. Where the correct answer for each item was given one score 1 , and score 0 if the answer was incorrect. Thus, the total number of high scores obtained by a student was 35 and the total minimum score was 0 .

\section{Validity of the Achievement Test}

There are several criteria that need to be evaluated in order to validate the achievement test. And these criteria include the followings:

\section{Content Validity}

After formulating the questions that are designed for this test, it was presented to some faculty staff experts and other educational supervisors to determine the validity of the test and its ability to measure what it was designed for. Also, the content validity (authenticity of the arbitrators) has been approved to confirm the validity of the test by presenting the test in its preliminary form. Five arbitrators among the faculty staffs at Jordanian universities and experts in the field of teaching methods, measurement, evaluation and educational management were presented onto the committee to confirm the significant of the test items, the appropriate degree of language, the adequacy of the items used alongside any suggestions they deem appropriate to be taken into consideration. In sense, their opinions, amendments and suggestions were taken into account to finalize the test. 


\section{Construct Validity}

In order to extract the valid indicators for all test items, it was applied to 30 students outside the study sample but from the study population, and further compute the Pearson Correlation Coefficient between each item and the test as a whole. The result is presented in Table 1.1 as follows:

Table 1.1: correlation coefficients between each item and the test as a whole

\begin{tabular}{cccccc}
\hline No & R. & No & R. & No & R. \\
\hline 1 & $.60^{* *}$ & 13 & $.76^{* *}$ & 25 & $.58^{* *}$ \\
2 & $.73^{* *}$ & 14 & $.65^{* *}$ & 26 & $.79^{* *}$ \\
3 & $.69^{* *}$ & 15 & $.72^{* *}$ & 27 & $.65^{* *}$ \\
4 & $.67^{* *}$ & 16 & $.64^{* *}$ & 28 & $.67^{* *}$ \\
5 & $.62^{* *}$ & 17 & $.63^{* *}$ & 29 & $.61^{* *}$ \\
6 & $.55^{*}$ & 18 & $.64^{* *}$ & 30 & $.55^{* *}$ \\
7 & $.67^{* *}$ & 19 & $.67^{* *}$ & 31 & $.67^{* *}$ \\
8 & $.63^{* *}$ & 20 & $.79^{* *}$ & 32 & $.61^{* *}$ \\
9 & $.57^{* *}$ & 21 & $.65^{* *}$ & 33 & $.77^{* *}$ \\
10 & $.64^{* *}$ & 22 & $.61^{* *}$ & 34 & $.55^{* *}$ \\
11 & $.75^{* *}$ & 23 & $.72^{* *}$ & 35 & $.68^{* *}$ \\
12 & $.48^{*}$ & 24 & $.68^{* *}$ & & \\
\hline
\end{tabular}

Note: * correlation coefficients and statistical significant at $(\alpha \leq 0.05)$

** Correlation coefficients and statistical significant at $(\alpha \leq 0.01)$

Results from Table 1.1 shows that the correlation coefficients between each item of the test and the test as a whole were between 0.48 to 0.79 which are satisfied and consistent with the study objectives.

\section{Difficulties and Discriminate Indices}

Both difficulty and discriminate indices were extracted for the test items. The results are presented in Table 1.2 as follows:

Table 1.2: Difficulties and Discriminate Indices for all Items of the Test

\begin{tabular}{lcccccccc}
\hline No. & Dif. & Dis. & No. & Dif. & Dis. & No. & Dif. & Dis. \\
\hline 1 & 0.46 & 0.53 & 13 & 0.61 & 0.66 & 25 & 0.46 & 0.58 \\
2 & 0.51 & 0.61 & 14 & 0.58 & 0.64 & 26 & 0.60 & 0.67 \\
3 & 0.61 & 0.69 & 15 & 0.53 & 0.59 & 27 & 0.61 & 0.69 \\
4 & 0.66 & 0.68 & 16 & 0.55 & 0.62 & 28 & 0.66 & 0.70 \\
5 & 0.56 & 0.60 & 17 & 0.47 & 0.57 & 29 & 0.53 & 0.60 \\
6 & 0.58 & 0.61 & 18 & 0.52 & 0.56 & 30 & 0.69 & 0.72 \\
7 & 0.55 & 0.59 & 19 & 0.49 & 0.58 & 31 & 0.58 & 0.66 \\
8 & 0.56 & 0.62 & 20 & 0.66 & 0.69 & 32 & 0.62 & 0.68 \\
9 & 0.54 & 0.66 & 21 & 0.60 & 0.64 & 33 & 0.49 & 0.55 \\
10 & 0.48 & 0.57 & 22 & 0.61 & 0.66 & 34 & 0.57 & 0.61 \\
11 & 0.52 & 0.59 & 23 & 0.62 & 0.68 & 35 & 0.50 & 0.68 \\
12 & 0.62 & 0.68 & 24 & 0.59 & 0.65 & & & \\
\hline
\end{tabular}


Results in Table 1.2 shows that the values of difficulty coefficients were at the range of 0.46 to 0.69 hence, consistent with the literature. While the values of the discriminate coefficients were between 0.53 to 0.72 which are considered as satisfied values for the study.

\section{Reliability of the Achievement Test}

It was established from the estimation that the test was reliable by applying it to a survey sample from a research community consisting of 30 male and female sample students. The test was further applied two times within two weeks on the same survey sample. Pearson Correlation Coefficient was computed between the two applications to extract the reliability of the return. The reliability of the instrument was also confirmed by extracting its coefficient of reliability using the Kuder-Richardson equation. The values of the Koder Richardson coefficient were 0.81 and the reliability coefficient was found at 0.87 , which are considered satisfactory and consistent with the study philosophy.

\section{Study Procedures}

The following procedures were followed to implement the study philosophy:

i. Referring to theoretical literature and previous studies about the subject of the study.

ii. Selecting the students from third grade level, where the school administration and teachers collaborated to facilitate the experiment and application of the study, and the sample students were divided into two (2) groups.

iii. Obtaining books to facilitate the task of the study and later addressed to the school administration to which this study was applied.

iv. Selecting some computerized learning games in teaching English that are suitable for third grade students.

v. Preparing the study instrument (collection check) and verify the indicators of validity and reliability.

vi. Verifying the equivalence between members of the control and experimental groups in English language.

vii. Applying the pre-test for students in the control and experimental groups.

viii. Ensuring the availability of devices and tools that can be applied in the study, such as computers connected to the Internet, the availability of software required for the operation of computerized games, the number of computers compatible with the number of students, and validity of computerized games to work on devices.

ix. Carrying out the study through teaching the targeted respondents among the control group in a traditional teaching method, while teaching experimental group participants using the computerized learning games during the first semester of academic year $2017 / 2018$.

x. The study is conducted within the period of four (4) weeks starting from the period $25 / 11 / 2018$ to $21 / 12 / 2017$. Experimental group participants were taught the seventh and eighth units of the Action Pack 3 along with the textbook, whereas the control group was taught by the seventh and eighth units of Action Pack 3 in a traditional way.

xi. Applying the post-application of achievement test for the participants of the control and experimental groups. 
Vol. 7, No. 2, April 2018, E-ISSN: 2226-6348 @ 2018 HRMARS

xii. Entering the collected and monitored data into the computer and doing the appropriate statistical processing using the SPSS program to reach, discuss and interpret the results and further provides a set of recommendations and suggestions in light of the concluded results.

\section{Results and Discussions}

To answer the first research question with its corresponding objectives, the means and standard deviations were obtained for the achievement of third grade students in English language subject at Karak schools according to post measurement. The results are presented in Table 1.3 as follows:

Table 1.3: The means and standard deviation according to post measurement

\begin{tabular}{llccc}
\hline \multirow{2}{*}{ Group } & \multicolumn{1}{c}{ Category } & \multicolumn{2}{c}{$*$ Post } & \%* \\
\cline { 3 - 4 } & & Mean & Std Deviation & \\
\hline \multirow{2}{*}{ Experimental } & Males & 16.40 & 5.26 & 46.86 \\
& Females & 17.60 & 4.45 & 50.29 \\
& Total & 17.00 & 4.82 & 48.57 \\
Control & Males & 18.13 & 3.64 & 51.80 \\
& Females & 18.33 & 3.43 & 52.37 \\
\multirow{3}{*}{ Total } & Total & 18.23 & 3.48 & 52.09 \\
& Males & 17.26 & 4.53 & 49.31 \\
& Females & 17.96 & 3.92 & 51.31 \\
& Total & 17.61 & 4.22 & 50.31 \\
\hline
\end{tabular}

Note: * indicates a total degree 35

$* *$ indicates a $100 \%$

Available information contained in Table 1.3 shows that the mean of the students' achievement in the pre-test for the control group is 18.23 from 35 by $52.09 \%$, while the mean of student's achievement in the pre-test for the experimental group is 17.00 by $48.57 \%$. In both groups, the total number of students (17.61) was 35 and by $50.31 \%$. This indicates that the level of students' achievement is medium. The study justifies that English language is divided into four skills namely; listening, reading, speaking and writing. These skills depend on each other to a varying degrees. Also, English is to be generally practiced. It is well-known that the language used in Karak is Arabic and therefore English is used only at school classes and is considered by both students and parents to be difficult to learn. Thus, students may not get high scores. English teaching receives a share of state care at public schools; as it is the language of science and technology, the language of research and scientific conferences, the language of international humanitarian, relief and medical organizations, the language of economics and e-commerce, and teaching it is one of the most important means of collecting Knowledge.

Furthermore, it might be that students' achievement at the third grade in English language at Karak schools is not high due to several factors. Some of these factors includes the school curriculum and is limited in providing students with information and does not take into account the individual differences, the difficulty of content and organizing it. In addition, Many teachers especially the old ones, still use the traditional method of teaching English, the frequent use of Arabic language during the lesson, limited use of modern teaching techniques, the inability of 

DEVELOPMENT

Vol. 7, No. 2, April 2018, E-ISSN: 2226-6348 @ 2018 HRMARS

some teachers to deal with the curriculum or their inability to speak English fluently, as well as students are not interested in doing homework nor being followed-up by their parents who use English poorly.

To answer the second research question, the means and standard deviations of the pre and post measurements of control and experimental groups were obtained. Both the analysis of Covariance and the $t$-test were applied to the pre measurement to extract equivalence between the two groups as presented in the following Table 1.4:

Table 1.4: Equivalence of the two groups in the pre measurement according to gender and group variables

\begin{tabular}{lllcccc}
\hline Variable & Category & N. & Mean & Std Dev & t-value & Sig. \\
\hline The & Control & 30 & 17.00 & 4.83 & \multirow{2}{*}{$1.135-$} & \multirow{2}{*}{0.261} \\
group & Experimental & 30 & 18.23 & 3.48 & & \\
Gender & Male & 30 & 17.27 & 4.53 & \multirow{2}{*}{0.639} & 0.525 \\
& Female & 30 & 17.97 & 3.93 & &
\end{tabular}

Table 1.4 shows the results of equivalence of the two groups in the pre measurement. The results indicated that the $t$ - values are not significant at $(\alpha \leq 0.05)$ for the achievement of third grade students among English subject in the pre measurement according to gender variable. This indicates that there is equivalence between the two groups.

Furthermore, the pre, post and modified means for the achievement of third grade students in English language according to the gender and group variables are equally estimated, and the results are shown in the following Table 1.5.

Table 1.5: Means, standard deviations and modified means according to the group and gender variables

\begin{tabular}{llccccc}
\hline \multirow{2}{*}{ Group } & Gender & \multicolumn{2}{c}{ Pre-mean } & \multicolumn{2}{c}{ Post-mean } & Modified \\
\cline { 3 - 6 } & & Mean & Std Dev & Mean & Std Dev & means \\
\hline Experimental & Males & 16.40 & 5.26 & 28.46 & 3.11 & 28.35 \\
& Females & 17.60 & 4.45 & 29.66 & 3.86 & 29.66 \\
\multirow{4}{*}{ Control } & Total & 17.00 & 4.82 & 29.06 & 3.50 & 29.01 \\
& Males & 18.13 & 3.64 & 23.93 & 4.72 & 23.98 \\
& Females & 18.33 & 3.43 & 25.66 & 3.97 & 25.73 \\
Total & Total & 18.23 & 3.48 & 24.80 & 4.38 & 24.85 \\
& Males & 17.26 & 4.53 & 26.20 & 4.55 & 26.16 \\
& Females & 17.96 & 3.92 & 27.66 & 4.35 & 27.69 \\
& Total & 17.61 & 4.22 & 26.93 & 4.48 & 26.93 \\
\hline
\end{tabular}

Results presented in Table 1.5 shows that there are significant differences between the means of third grade students' achievement in English language according to the group and gender variables in the pre and post scales. To illustrate the significance of the statistical differences between the means of third grade students' achievement in English language according to the (group, gender) variables and the interaction between them in the post-scale, ANCOVA and ETA $\left(n^{2)}\right)$ were applied to detect the impact strength of the use of computerized games as illustrated in Table 1.6. 
INTERNATIONAL JOURNAL OF ACADEMIC RESEARCH IN PROGRESSIVE EDUCATION AND DEVELOPMENT

Vol. 7, No. 2, April 2018, E-ISSN: 2226-6348 @ 2018 HRMARS

Table 1.6: ANCOVA analysis according to the group and gender variables

\begin{tabular}{lcccccc}
\hline \multicolumn{1}{c}{ S.V } & SS & Df & MS & F. & Sig. & ES \\
\hline Group & 253.424 & 1 & 253.424 & 15.999 & 0.000 & 0.225 \\
Gender*group & 34.832 & 1 & 34.832 & 2.199 & 0.144 & 0.038 \\
Pre & 0.736 & 1 & 0.736 & 0.046 & 0.830 & 0.001 \\
Error & 8.148 & 1 & 8.148 & 0.514 & 0.476 & 0.009 \\
Total & 871.185 & 55 & 15.840 & & & \\
corrected & & & & & & \\
& 1185.733 & 59 & & & & \\
\hline
\end{tabular}

As presented in Table 1.6, results show that there are significant differences at $(\alpha \leq 0.05)$ between the mean of third grade students' achievement in English language in the post-measurement according to the variable (group), where the $F$ value of the group variable is 15.999 and statistically significant at $1 \%(0.000)$. The effect size was obtained by the value of ETA $(\eta 2)$ at 0.225 ; that is, the effect ratio is at $22.5 \%$. The differences were for the experimental group, while the experimental mean is 29.01 and for the control group is 24.85 . In addition, there are no significant differences at $(\alpha \leq 0.05)$ in the pre scale where the $F$ value is 0.514 and found to be significant at $5 \%$ level. This result therefore confirms the equivalence between the two groups before the statistical process.

Further results showed that the level of development in experimental group that was taught by computerized learning games for some English lessons is greater than the control group taught by traditional method. This is due to the impact of using computerized learning games which can attracts students' attention and thus increases the degree of concentration, leading to the stability of information and the ability to retrieve them when needed during the exams periods and raising their academic achievement. Also, the principles of various electronic learning games are to use audio and visual effects in addition to other elements of interest and attraction alongside the sense of doing competitions among students by interesting methods.

Generally, the third grade students prefer to play with anything. Hence playing games in education are designed to develop theoretical ideas in practice and it is a cooperative activity involving active participation in a kind of fun and raising their motivation to learn. Third grade students also prefer to use the strategy of playing English language skills to feel fun and get benefited at the same time through open-close activities since they like to know when the game starts and when it ends. This eventually assisted them to develop a strategy towards finishing the game on time after the questions are being answered.

Using e-learning games has proven to be a successful method that assisted in creative learning, discovery and experimentation especially for first-grade students. More so, electronic learning games help reduce the gap between what takes place inside the classroom and what students encounter in their daily lives, reduce the psychological stress, and reduce the degree of fear of the curriculum. Likewise, learning games are important and effective means of providing the students with alphabets and vocabulary knowledge. The method stimulates the learner's motivation and interferes with learning. The learners like playing games; through this approach, many of them improves their language development.

Accordingly, teachers use games in the classroom to help learners acquire language in an interesting and enjoyable way. Games assisted in teaching numerous areas of language, such as 


\section{INTERNATIONAL JOURNAL OF ACADEMIC RESEARCH IN PROGRESSIVE EDUCATION AND}

DEVELOPMENT

Vol. 7, No. 2, April 2018, E-ISSN: 2226-6348 @ 2018 HRMARS

vocabulary, grammar, and linguistic patterns. Also, games help to give the children important values such as respect for others and some social skills including having sound leadership roles. These findings are also consistent with the results of Abu Jaber et al. (2002) who showed the positive impact of using language games in reading texts. Furthermore, it is also consistent with the results from Ibrahim (2011), whose findings indicated a differences of statistical significance between the mean total student scores for the control and experimental groups in the post-test at the level of memory and testing as a whole for the experimental group, and the impact of electronic learning games on the students' achievement at fifth grade.

Notwithstanding, the results are equally consisted with the study findings of Al-Rimawi (2014) who showed that there were significant differences between the mean direct and deferred achievement of the sixth grade students in English language for the experimental group, and also consistent with the study by Mehrpour (2017) who showed that the use of computerized learning games had a significant impact on learning English spelling in general and on learning English words within silent messages especially among the experimental group. Contrary to this, the study findings of Al-Mashaqbeh (2015) indicated that there are no any statistically significant differences between the mean achievement of group scores in the Arabic language between the experimental and the control groups.

For the third questions, the results previously shown in Table 1.6 indicated that there are no statistically significant differences at $(\alpha \leq 0.05)$ in the gender variable, since the $F$ value of 2.199 has a $p$-value of no significance 0.144 at $5 \%$ level. Moreover, the results showed no statistically significant differences at $(\alpha \leq 0.05)$ according to the interaction between gender and the group since the $F$ value of 0.046 has its corresponding $p$-value of 0.830 statistically not significance at $5 \%$ level. The study explained that the curriculum is unified for all students; both males and females. In addition, the possibilities of available technical facilities such as computers, internet and learning classrooms are equal at both male and female schools. Still, most schools follow coeducation from the $1^{\text {st }}$ to the $4^{\text {th }}$ grades, so that male and female students at these levels receive the same level of education and from a single social environment. In general, these results are consistent with Al-Mashaqbeh's (2015) which showed no significant differences between the mean scores of the experimental group who were taught by using the computer program and the mean score of control group due to gender variable.

\section{Conclusions}

This study examined the effects of using computerized learning games on the third grade students within Karak Governorate and further evaluates the achievements recorded in the application of English language at various schools and its impact on English language development.

The estimated findings showed that the level of students' achievement at the third grade before utilizing the electronic games in teaching English language was medium among the experimental and control groups. It has also proven that the use of computerized learning games in teaching English for the third grade at primary schools in Karak Governorate is effective in raising the students' achievement for third grade in a significant direction. In light of the results of this study therefore, there is need to recognize the significant effects of computerized learning games in the design of educational policies. The essential relevance of these computer learning games 
Vol. 7, No. 2, April 2018, E-ISSN: 2226-6348 @ 2018 HRMARS

cannot be undermined particularly in the contemporary era, hence the growing need by the government to advocates publicity campaign towards national growth and development.

\section{Recommendations}

In view of the estimated findings and the current position of literature, this study offers some feasible policy recommendations that would improve and enhance the educational process. $A$ number of these recommendations are given as follows:

i. There is need to further encourage the application of computerized learning games in teaching English language since the technology has proven its impact on increasing and raising the achievement' level in English language among students;

ii. Curriculum developers in the Ministry of Education should develop learning programs in English language to support teaching based on computerized learning games; and

iii. The Ministry of Education should provide adequate facilities, electronic and technological devices considered necessary for effective operations and use of computerized learning games towards teaching English language and developing the students' skills in terms of reading, writing, listening, and speaking; as well as provides a well-equipped English language structure to teach all students in a developed and modern manner.

\section{Acknowledgement}

This article is part of a research fund sponsored by Center for Research and Innovation (RMIC), Universiti Sultan Zainal Abidin (UniSZA), Gong Badak Campus 21300 Kuala Nerus, Terengganu.

\section{References}

Abdel Baqi, S. M. (2001). Playing between theory and practice. Egypt: Alexandria Book Center.

Al-Abadi, H. M, \& Jaradat, Y. A. (2015). The impact of the use of the electronic mental map in the development of reading comprehension in the English language in the ninth grade students. The Jordanian Journal of Educational Sciences, 11 (4), 469-480.

Al-Ahmadi, A.A. (2011). The impact of using learning games in the acquisition of students of the sixth grade primary alphabets and vocabulary of the English language in Jeddah (unpublished master's thesis). University of Umm al-Qura, Saudi Arabia.

Al-Anani, H. (2002). Play among children, theoretical bases and application. Amman: Dar Al Fikr for Printing and Publishing.

Al-Ghazu, E. (2004). Integrating techniques into education (technically preparing the teacher for the third millennium). United Arab Emirates: Dar Al Qalam Publishers.

Al-Helah, M. M. (2002). Education technology between theory and practice ( $2^{\text {nd }}$ ed). Amman: Dar Al Maserah.

Al-Helah, M. M, \& Ghanem, A. A (2002). The effect of computerized and traditional language educational games in addressing reading difficulties among grade students. An-Najah University Journal of Research, Humanities, 16 (2). 589-626.

Al-Mashaqbeh, I., \& Neama, M. (2015). The effect of computerized instructional program in the intermediate first grade students' achievement in Arabic language grammar in Iraq. Journal of Education and Practice, 6 (32), 21-26. 
INTERNATIONAL JOURNAL OF ACADEMIC RESEARCH IN PROGRESSIVE EDUCATION AND DEVELOPMENT

Vol. 7, No. 2, April 2018, E-ISSN: 2226-6348 @ 2018 HRMARS

Al-Rimawi, F. T (2014). The impact of the use of learning in English teaching on direct and deferred achievement among sixth grade students inAmman Governorate (Unpublished Master's thesis). Middle East University, Amman, Jordan).

Alshourafa, A. (2012). The effect of motivation on Jordanian 10th grade students' writing skills in English. European Scientific Journal, 8 (22), 235-247.

Ibrahim, M. O. (2011). The impact of electronic learning games on educational achievement: case study of fifth grade students in Khartoum local schools (unpublished Master's thesis). Sudan University of Science, Khartoum.

Leonard, L. M., \& Tracy, D. M. T. (1993). Using games to meet the standards for middle school students. Arithmetic Teacher, 40 (9), 499-504.

Mansi, M. (1991). The social and economic level of the family and its relation to parental trends and the educational achievement of the children. Cairo: Scientific Book House.

Melhem, S. (2002). The use of play in the teaching of scientific concepts and information in mathematics for the fifth grade primary, Journal of King Saud University, Educational Sciences and Islamic Studies, 14 (1), 731768.

Mehrpour, S., \& Ghayour, M. (2017). The effect of educational computerized games onlearning English spelling among Iranian children. The Reading Matrix: An International Online Journal, 17(2), 168-175.

Moreno-Ger, P., Burgos, D., Martínez-Ortiz, I., Sierra, J. L., \& Fernández-Manjón, B. (2008). Educational game design for online education. Computers in Human Behavior, 24(6), 25302540.

Mumtaz, S. (2001). Children's enjoyment and perception of computer use in the home and the school. Computers and Education, 36 (4), 347-362.

Najm, K. (2001). The impact of the use of educational sports games for the seventh grade students on both their acquisition in mathematics and their attitudes toward them (unpublished Master's thesis). University of Jordan, Jordan.

Nofal, K. (2011). The reasons behind the English major students' weaknesses in Philadelphia University. Damascus University Journal, 27 (1), 101-128.

Oldfield, B. J. (1991). Games in the Learning of Mathematics: 1: A Classification. Mathematics in School, 20 (1), 41-43.

Obied, H. (2007). Children's games and parties. Amman: Dar Al Yazouri Scientific Publishing and Distribution.

Qadeh, A. M. (2003). The effectiveness of computerized learning in the teaching of English grammar in secondary schools in Makkah Al Mukarramah (Unpublished Master's thesis). Umm Al Qura University, Saudi Arabia.

Qandil, M. M., \& Badawi, R. M. (2007). Learning Games in Early Childhood. Amman: Dar Al Fikr for Publishing and Distribution.

Shokri, H., \& Abdolmanafi-Rokni, S. J. (2014). The impact of computer games on EFL learners' spelling: A qualitative study. Studies in English Language Teaching, 2 (3), 266-274.

Tahaineh, Y., \& Daana, H. (2013). Jordanian undergraduates' motivations and attitudes towards learning English in EFL context. International review of social sciences and humanities, 4(2), 159-180. 